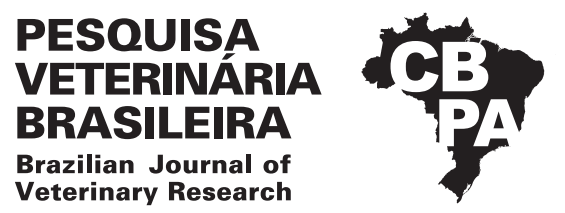

Pesq. Vet. Bras. 38(8):1471-1474, agosto 2018 DOI: 10.1590/1678-5150-PVB-5530

Original Article

Animais de Produção/Livestock Diseases

ISSN 0100-736X (Print)

ISSN 1678-5150 (Online)

\title{
Poisoning by Senna obtusifolia in sheep ${ }^{1}$
}

\author{
Édipo M. Campos ${ }^{2}$, Lisanka Â. Maia ${ }^{3}$, Roberio G. Olinda², Eduardo M. Nascimento ${ }^{2}$, \\ Diego B. Melo ${ }^{4}$, Antônio Flávio M. Dantas ${ }^{2}$ and Franklin Riet-Correa ${ }^{5 *}$
}

\begin{abstract}
Campos E.M., Maia L.A., Olinda R.G., Nascimento E.M., Melo D.B., Dantas A.F.M. \& Riet-Correa F. 2018. Poisoning by Senna obtusifolia in sheep. Pesquisa Veterinária Brasileira 38(8):1471-1474. Laboratório de Patologia Animal, Hospital Veterinário, Universidade Federal de Campina Grande, Avenida Universitária s/n, Santa Cecília, Patos, PB 58700-970, Brazil. E-mail: edipo_mc1@hotmail.com

In a paddock highly invaded by Senna obtusifolia 10 out of 60 sheep showed muscle weakness and 9 died after a clinical manifestation period of 24-76 hours. Serum activities of creatine kinase were increased in all sheep examined. Multifocal polyphasic muscle segmental degeneration and necrosis was observed in skeletal muscles. Although the plant is a common weed in northeastern Brazil, the poisoning is rare, probably because the animals do not ingest it or due to toxicity variations.
\end{abstract}

INDEX TERMS: Poisonous plants, Senna obtusifolia, sheep, plant poisoning, toxic myopathy, segmental muscle necrosis, toxicoses.

RESUMO.- [Intoxicação por Senna obtusifolia em ovinos.] Em um piquete altamente invadido por Senna obtusifolia, 10 de 60 ovelhas mostraram fraqueza muscular e 9 morreram após um período de manifestação clínica de 24-76 horas. As atividades séricas da creatina quinase foram aumentadas em todos os ovinos examinados. Foi observada degeneração segmentar e necrose polifásica muscular em músculos esqueléticos. Embora a planta seja uma erva daninha comum no Nordeste do Brasil, o envenenamento é raro, provavelmente porque os animais não o ingerem ou devido a variações de toxicidade.

TERMOS DE INDEXAÇÃO: Plantas tóxicas, Senna obtusifolia, ovinos, intoxicação por plantas, miopatia tóxica, necrose segmentar do músculo, toxicoses.

\footnotetext{
${ }^{1}$ Received on July 11, 2017.

Accepted for publication on July 26, 2017.

Part of the first author's Master Dissertation.

${ }^{2}$ Programa de Pós-Graduação em Medicina Veterinária, Universidade Federal de Campina Grande (UFCG), Avenida Universitária s/n, Bairro Santa Cecília, Patos, PB 58708-110, Brazil.

${ }^{3}$ Laboratório de Patologia Veterinária, Hospital Veterinário, Instituto Federal da Paraíba, Sousa, PB 58800-970, Brazil.

${ }^{4}$ Médico Veterinário autônomo, São Bento, Paraíba, PB 58865-000, Brazil.

${ }^{5}$ Instituto Nacional de Investigación Agropecuaria (INIA), La Estanzuela, Colonia Uruguay, CP 70.000, Uruguay. *Corresponding author: frcorrea@inia.org.uy, franklinrietcorrea@gmail.com
}

\section{INTRODUCTION}

The genus Senna (Leguminoseae Caesalpinioideae) is constituted by nearly 300 species with a circumtropical distribution (Souza \& Bortoluzzi 2012). Poisoning by Senna obtusifolia in cattle was reported as a cause of segmental muscle degeneration and necrosis in United States of America (Henson et al. 1965, Nicholson et al. 1977, McCormack \& Neisler 1980) and southern and central-western Brazil (Froehlich 2010, Queiroz et al. 2012, Carvalho et al. 2014, Furlan et al. 2014). Poisoning by Senna occidentalis seeds or leaves had been reported in horses (Oliveira-Filho et al. 2013) and pigs (Martins et al. 1986) in southern Brazil, and cattle from Texas (Henson et al. 1965, Pierce \& O'Hara 1967) and southern Brazil (Barros et al. 1990, 1999, Barth et al. 1994, Carmo et al. 2011). Despite some experimental poisonings with S. occidentalis in goats (Dollahite et al. 1964, Suliman et al.1982, Barbosa-Ferreira et al. 2011) and sheep (Dollahite et al. 1964) and with S. obtusifolia in sheep (Lopes et al. 2016) with variable results, the spontaneous poisoning by Senna spp. has not been reported in small ruminants.

The objective of this paper is to report the epidemiology, clinical signs, and pathology of the poisoning by S. obtusifolia in sheep grazing a paddock severely invaded by this plant.

\section{MATERIALS AND METHODS}

Epidemiological data and the history of the outbreak were collected on visits to the farm located in the of municipality of São Bento $\left(6^{\circ} 30^{\prime} 18,79^{\prime \prime} \mathrm{S}, 37^{\circ} 28^{\prime} 23,97^{\prime \prime} \mathrm{W}\right)$ in the state of Paraíba, Brazil. 
Blood was collected in four affected sheep. Serum activities of aspartate aminotransferase (AST) and creatine kinase (CK) were determined by enzyme kinetic method according to the methods described in the automatic biochemical analyzer Roche ${ }^{\circledR}$ model Cobas c-111Atc.

Four sheep were necropsied and samples of liver, lung, kidney, heart, pancreas, adrenal, spleen, gut, pre-stomachs, abomasum, lymph nodes, urinary bladder, thyroids, skeletal muscles, brain, and spinal cord were fixed in buffered $10 \%$ formalin, embedded in paraffin, cut at $4-5 \mu \mathrm{m}$ and stained by hematoxylin and eosin (HE).

\section{RESULTS}

The outbreak occurred in July 2014. The sheep were in a semi-extensive system, grazing in a paddock with 1.5 hectare severely invaded by Senna obtusifolia and supplemented with corn bran and mineral salt. The farmer reported that the first sheep died 48 days after the introduction in the paddock invaded by $S$. obtusifolia. At this time, the paddock was short of forage (Fig.1) and the animals had consumed large amounts of $S$ obtusifolia leaves and pods. A voucher specimen of the plant is deposited at the herbarium of Federal University of Campina Grande with the accession number 3041.

The flock consisted of 60 crossbred (Santa Inês x Dorper) sheep and 15 Saanen and crossbred goats. Ten (16.6\%) adult sheep were affected in a 10 days period. Clinical signs were muscle weakness, reluctance to move, head dropping (Fig.2A), tremors, brown urine, and regurgitation of rumen content. The animals remained eating and drinking water. Later, the sheep remained in sternal recumbence followed by lateral recumbence. Nine sheep died after a clinical manifestation period of 24-76hs and one recovered. The CK activities were highly increased in the four sheep: 916.2, 606.7, 643.8 and 1535UI/L, in Sheep 1, 2, 3 and 4 respectively. The AST activities were increased in Sheep 1 and 4 (712 and 707UI/L) and within normal ranges in Sheep 2 and 3 (240 and 235UI/L).

Nine of the affected sheep died and one recovered. At necropsy, the liver of Sheep 1, 2, and 3 showed increased lobular pattern. In Sheep 1, the kidneys were diffusely reddened and in Sheep 2 and 3 were pale. In Sheep 4, the biceps femoris and the masseter muscles showed irregular areas of paleness. Seeds of $S$. obtusifolia were observed in the rumen content.

Histologically, multifocal, polyphasic segmental muscular degeneration and necrosis was observed in all sheep necropsied. Those lesions were severe in the longissimus lumbar, biceps femoris and semimembranosus muscles and moderate in the supra spinous, triceps brachial, diaphragm, masseter, and tongue. There were various degrees of hyaline, discoid and floccular degeneration of the myofibers, moderate infiltrate of mononuclear cells and macrophages phagocyting necrotic fibers in the interstitium and sarcoplasm, and proliferation of satellite cells with regeneration of myofibers and myotube formation (Fig.2B).

In Sheep 1, moderate centrilobular or midzonal vacuolation of hepatocytes were observed in the liver. Occasionally, there were eosinophilic hyaline proteinaceous inclusions (cytosegrosomes) within the hepatocytes. Mild to moderate vacuolation of centrilobular hepatocytes were observed in Sheep 2, 3 and 4 .

No clinical signs were observed in the 15 goats grazing at the same time with the affected sheep flock.

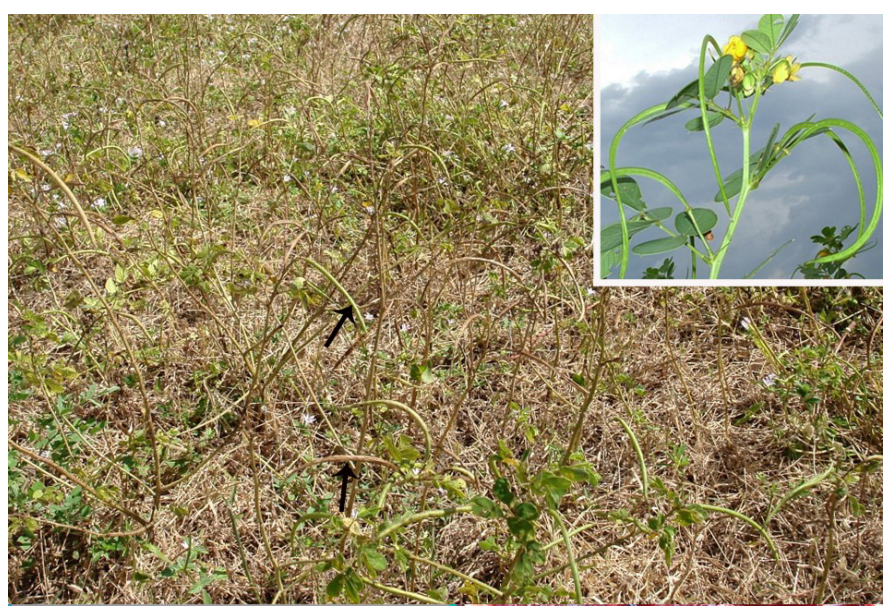

Fig.1. Pasture severely invaded by Senna obtusifolia with numerous pods (arrows). Inset: Flowers, pods and leaves of S. obtusifolia.

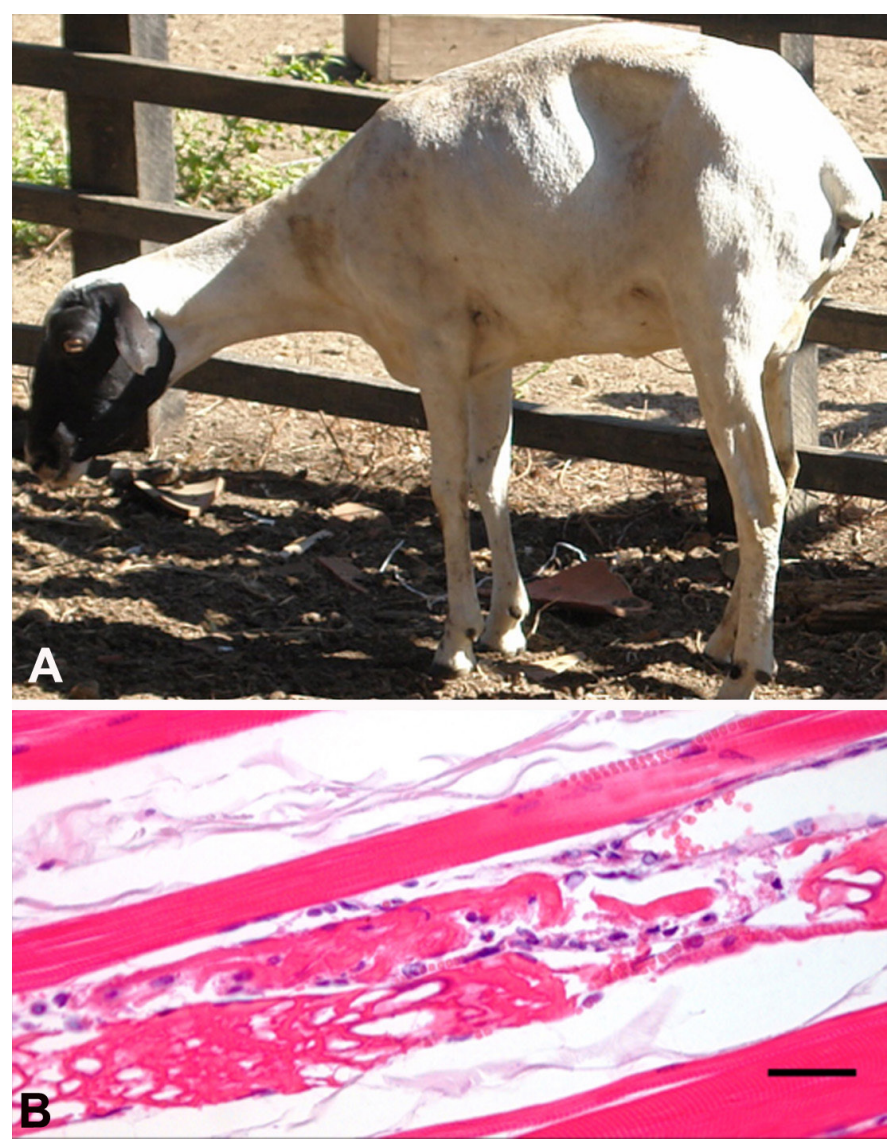

Fig.2. (A) Ewe poisoned by Senna obtusifolia showing muscle weakness, reluctance to move, and head dropping. (B) Biceps femoris muscle from Sheep 4 showing severe segmental degeneration of myofibers, with infiltration of mononuclear cells and macrophages, and proliferation of satellite cells. $\mathrm{HE}$, bar $=20 \mu \mathrm{m}$.

\section{DISCUSSION}

The diagnosis of Senna obtusifolia poisoning in sheep was based on the clinical signs and lesions, characteristic of segmental muscular degeneration and necrosis, and in the occurrence of the disease in a paddock with marked forage shortage and severely invaded by the plant, which showed 
evidences of being consumed by the sheep. The shortage of forage was due to a high stocking rate (53 sheep and goats in an area of 1.5 hectare during 40 days) at the start of the dry season. These epidemiologic conditions are similar to those reported in outbreaks of $S$. obtusifolia poisoning in cattle (Henson et al. 1965, Queiroz et al. 2012, Carvalho et al. 2014, Furlan et al. 2014).

Senna obtusifolia is a common weed in Northeastern Brazil; however, the poisoning has not been reported previously in ruminants in this region. It should be determine if this situation is due to fact that the plant is only consumed when there is shortage of forage and/or high stocking rate or if there are variations in the toxicity of the plant. In an experimental reproduction of the poisoning in cattle, it was suggested that there are variation in the toxicity of the plant from different places and in different seasons (Furlan et al. 2014). The toxic compound of S. obtusifolia and S. occidentalis has not been definitively isolated and characterized. Anthraquinone derivates including chrysophanic acid, physcion, obtusofolin, emodin, questin, obtusin, chrysoobtusin, and aurantiuoobtusin, have been identified in S. obtusifolia (Lewis \& Shibamoto 1989, Crawford et al. 1990). Naturally occurring quinones and quinone-containing extracts of seeds of S. obtusifolia affected muscle mitochondrial function (Lewis \& Shibamoto 1989). Anthraquinone derivatives, in addition to N-methylmorpholine, toxic alkaloids, toxalbumins, had also been identified in S. occidentalis (Crawford et al. 1990, Gebrelibanos et al. 2014). It is suggested that the muscular lesions caused by $S$. occidentalis are due to dianthrone, an anthraquinone derivate, which affects mitochondrial function interfering with oxidative phosphorylation leading to death of the organelle and segmental muscle degeneration (Cavaliere et al. 1997).

In the present outbreak, the clinical signs and pathology in sheep were similar to that observed in poisoning by S. obtusifolia and S. occidentalis in cattle, characterized by segmental degeneration and necrosis in striated muscles accompanied by high CK serum activity, myoglobinuria in most cases, and different degrees of liver lesions (Carvalho et al. 2014, Furlan et al. 2014). In previous experiments with small ruminants, it was not demonstrated that Senna spp. poisoning causes segmental degeneration and necrosis in striated muscles (Dollahite et al. 1964, Suliman et al. 1982, Barbosa-Ferreira et al. 2011, Lopes et al. 2016). In one report, 1 out of 6 goats that ingested $4 \%$ of S. occidentalis seeds in the food, daily, during the gestation period, showed mild lesions in skeletal muscles (Barbosa-Ferreira et al. 2011).

In the differential diagnosis, we should consider other nutritional or toxic myopathies including selenium/vitamin E deficiency and poisoning by ionophore antibiotics. The poisoning by ionophore antibiotics was ruled out because these drugs were not being used in the food. In addition, the clinical picture of ionophore antibiotics poisoning is characterized by muscular weakness and congestive cardiac insufficiency (Nogueira et al. 2009); in contrast, in the cases reported here no lesions were observed in the heart. In cattle poisoned by S. obtusifolia cardiac lesions were absent (Queiroz et al. 2012, Carvalho et al. 2014) or in some animals were mild (Furlan et al. 2014). Absence or presence of mild cardiac lesions in some animals is also reported in the poisoning by S. occidentalis (Barros etal. 1999, Barros 2016, Lopes etal. 2016). Mineralization of muscle fibers is a characteristic of the muscle lesions in Se/vitamin E deficiency not observed in poisoning by S. obtusifolia. In addition, Se/vitamin E deficiency affects mainly young animals with rapid growth (Rosa et al. 2013). In contrast, the outbreak reported here affected adult sheep. Therefore, the epidemiological data and the pathology rule out deficiency of selenium/vitamin $\mathrm{E}$ as the cause of the disease.

\section{CONCLUSION}

Senna obtusifolia cause muscular segmental degeneration and necrosis in sheep in the Brazilian semiarid region. However, despite the plant being a common weed in the region, the poisoning is uncommon, probably because the animals do not ingest it or because there are variations on its toxicity.

Acknowledgements.- This project was financially supported by National Institute of Science and Technology for the Control of Poisonous Plants, CNPq, grant 573534/2008-0.

\section{REFERENCES}

Barbosa-Ferreira M., Pfister J.A., Gotardo A.T., Maiorka P.C. \& Górniak S.L. 2011. Intoxication by Senna occidentalis seeds in pregnant goats: prenatal and postnatal evaluation. Experim. Toxicol. Pathol. 63(3):263-268. <http:// dx.doi.org/10.1016/j.etp.2010.01.004> <PMid:20138744>

Barros C.S.L. 2016. Sistema muscular, p.663-702. In: Santos R.L \& Alessi A.C. (Eds), Patologia Veterinária. Roca, São Paulo.

Barros C.S.L., Ilha M.R.S., Bezerra Junior P.S., Langohr I.M. \& Kommers G.D. 1999. Intoxicação por Senna occidentalis (Leg. Caesalpinoideae) em bovinos em pastoreio. Pesq. Vet. Bras. 19(2):68-70. <http://dx.doi.org/10.1590/ S0100-736X1999000200003>

Barros C.S.L., Pilati C., Andujar M.B., Graça D.L., Irigoyen L.F., Lopes S.T. \& Santos C.F. 1990. Intoxicação por Cassia occidentalis (Leg. Caes.) em bovinos. Pesq. Vet. Bras. 10:47-58.

Barth A.T., Kommers G.D., Salles M.S., Wouters F. \& Barros C.S.L. 1994. Coffee senna (Senna occidentalis) poisoning in cattle. Vet. Human Toxicol. 36(6):541-545. <PMid:7900275>

Carmo P.M.S., Irigoyen L.F., Lucena R.B., Fighera R.A., Kommers G.D. \& Barros C.L.S. 2011. Spontaneous coffee Senna poisoning in cattle: report on 16 outbreaks. Pesq. Vet. Bras. 31(2):139-146. <http://dx.doi.org/10.1590/ S0100-736X2011000200008>

Carvalho A.Q., Carvalho N.M., Vieira G.P., Santos A.C., Franco G.L., Pott A., Barros C.S.L. \& Lemos R.A.A. 2014. Intoxicação espontânea por Senna obtusifolia em bovinos no Pantanal Sul-Mato-Grossense. Pesq. Vet. Bras. 34(2):147-152. <http://dx.doi.org/10.1590/S0100-736X2014000200009>

Cavaliere M.J., Calore E.E., Haraguchi M., Górniak S.L., Dagli M.L.Z., Raspantini P.C., Calore N.M.P. \& Weg R. 1997. Mitochondrial myopathy in Senna occidentalis feed chicken. Ecotoxicol. Environ. Safety 37(2):181-185. <http://dx.doi. org/10.1006/eesa.1997.1542> <PMid:9262958>

Crawford L., McDonald G.M. \& Friedman M. 1990. Composition of sicklepod (Cassia obtusifolia) toxic weed seeds. J. Agric. Food Chem. 38(12):21692175. <http://dx.doi.org/10.1021/jf00102a014>

Dollahite J.W., Henson I.B. \& Householder G.T. 1964. Coffee senna (Cassia occidentalis) poisoning in animals. Tex. Agric. Exp. Stn Progr. Rep. 2318, Texas A\&M University. $2 \mathrm{p}$.

Froehlich D.L. 2010. Intoxicação espontânea e experimental por folhas e vagens da planta Senna obtusifolia (Leguminosae) em bovinos. Dissertação de Mestrado. Available at <http://www.cav.udesc.br/arquivos/id_submenu/753/ diego_froehlich.pdf> Access on Apr. 18, 2014.

Furlan F.H., Zanata C., Damasceno E.S., Oliveira L.P., Silva L.A., Colodel E.M. \& Riet-Correa F. 2014. Toxic myopathy and acute hepatic necrosis in cattle caused by ingestion of Senna obtusifolia (sicklepod; coffee senna) in Brazil. Toxicon 92:24-30. <http://dx.doi.org/10.1016/j.toxicon.2014.09.007> $<$ PMid:25255730> 
Gebrelibanos M., Periyasamy G. \& Sintayehu B. 2014. Senna occidentalis seed: is it health risk or potential medicine? Int. J. Pharmacol. 1(3):161-167.

Henson J.B., Dollahite J.W., Bridges C.H. \& Rao R. 1965. Myodegeneration in cattle grazing Cassia specie. Am. J. Vet. Res. 147(2):142-145. <PMid:5892400>

Lewis D.C. \& Shibamoto T. 1989. Effects of Cassia obtusifolia (sicklepod) extracts and anthraquinones on muscle mitochondrial function. Toxicon 27(5):519-529. <http://dx.doi.org/10.1016/0041-0101(89)90113-X> $<$ PMid:2749752>

Lopes D.I.S., Sousa M.G., Ramos A.T. \& Maruo V.M. 2016. Cardiotoxicity of Senna occidentalis in sheep (Ovis aries). Open Vet. J. 6(1):30-35. <http:// dx.doi.org/10.4314/ovj.v6i1.5> <PMid:26894038>

Martins E., Martins V.M.V., Riet-Correa F., Soncini R.A. \& Paraboni S.V. 1986. Intoxicação por Cassia occidentalis (Leguminosae) em suínos. Pesq. Vet. Bras. 6:35-38.

McCormack J.E. \& Neisler W.E. 1980. Cassia obtusifolia (sicklepod) toxicity in a dairy herd. Vet. Med. Small Anim. Clin. 75(12):1849-1851. <PMid:6906898>

Nicholson S.S., Thornton J.T. \& Rimes A.J. 1977. Toxic myopathy in dairy cattle caused by Cassia obtusifolia in greenchop. Bov. Pract. 12:120.

Nogueira V.A., Franca T.N. \& Peixoto P.V. 2009. Intoxicação por antibióticos ionóforos em animais. Pesq. Vet. Bras. 29(3):191-197. <http://dx.doi. org/10.1590/S0100-736X2009000300001>
Oliveira-Filho J.P., Cagnini D.Q., Badial P.R., Pessoa M.A., Del Piero F. \& Borges A.S. 2013. Hepatoencephalopathy syndrome due to Cassia occidentalis (Leguminosae Caesalpinioideae) seed ingestion in horses. Eq. Vet. J. 45(2):240-244. <http://dx.doi.org/10.1111/j.2042-3306.2012.00599. $\mathrm{x}><$ PMid:22784255>

Pierce K.R. \& O'Hara P.J. 1967. Toxic myopathy in Texas cattle. Southwestern Vet. 20:179-183.

Queiroz G.R., Ribeiro R.C.L., Romão F.T.N.M.A., Flaiban K.K.M.C., Bracarense A.P.F.R.L. \& Lisboa J.A.N. 2012. Intoxicação espontânea de bovinos por Senna obtusifolia no estado do Paraná. Pesq. Vet. Bras. 32(12):1263-1271. <http://dx.doi.org/10.1590/S0100-736X2012001200009>

Rosa F.B., Caprioli R.A., Silva T.M., Galiza G.J.N., Barros C.S.L., Irigoyen L.F., Fighera R.A. \& Kommers G.D. 2013. Doenças de caprinos diagnosticadas na região Central no Rio Grande do Sul: 114 casos. Pesq. Vet. Bras. 33(2):199204. <http://dx.doi.org/10.1590/S0100-736X2013000200011>

Souza V.C.E. \& Bortoluzzi R.L.C. 2012. Senna. Lista de Espécies da Flora do Brasil, Jardim Botânico do Rio de Janeiro, Rio de Janeiro. Available at <http://floradobrasil.jbrj.gov.br/2012/FB023149>Access on Sept. 10, 2015.

Suliman H.B., Wasfi I.A. \& Adam S.E.I. 1982. The toxicity of Cassia occidentalis to goats. Vet. Hum. Toxicol. 24(5):326-330. <PMid:7135798> 